Annals of Warsaw University of Life Sciences - SGGW

Land Reclamation No 40, 2008: 39-44

(Ann. Warsaw Univ. of Life Sci. - SGGW, Land Reclam. 40, 2008)

\title{
Phytotoxicity and potential genotoxicity of Radiowo municipal landfill leachate
}

GRAŻYNA OBIDOSKA, DOROTA JASIŃSKA

Department of Environmental Protection, Warsaw University of Life Sciences - SGGW

\begin{abstract}
Phytotoxicity and potential genotoxicity of Radiowo municipal landfill leachate. The most common method of municipal solid waste disposal is storing at landfills. Many hazardous substances are present in garbage and some more are formed during degradation. They may be assimilated by numerous organisms, pass through the food chain and bioaccumulate by long-term exposure in animals and humans. Therefore it seems an important tusk to monitor the toxic and genotoxic potential of municipal landfill leachates, which may contaminate waters and soils. Higher plants provide a very useful, uncomplicated and inexpensive tool for first-step screening of environmental pollutants. The objective of our study was to evaluate the phytotoxicity and potential genotoxicity of Radiowo municipal landfill leachate by the means of plant bioassays and to preliminary valuate the efficiency of zeolite as a leachate purifier. Phytotoxicity was assessed by the Allium cepa Root Elongation Bioassay and genotoxicity by the means of Allium and Vicia Root Tip Assays (RTA). Results were subjected to the F-test for the two way analysis of variance (ANOVA 2) and subsequently the Tukey's test, with statistical significance set at $\mathrm{p}=0.05$. Applied plant bioassays indicated significant phytotoxicity and potential genotoxicity of Radiowo landfill leachate The process of zeolite filtration did not eliminate, but evidently decreased phytotoxicity. It did not cause significant change in genotoxic potential of $100 \%$ leachate, but resulted in its more rapid decrease in a concentration dependent manner.
\end{abstract}

Key words: leachate, phytotoxicity, genotoxicity, Allium, Vicia, Root Tip Assay.

\section{INTRODUCTION}

The most common method of municipal solid waste disposal is storing at landfills. Many hazardous substances are present in garbage and some more are formed during degradation. Penetration of precipitation through the waste heap generates leachates, which may contaminate waters and soils and pose a serious impact to the environment. Toxic substances could be assimilated by numerous organisms, pass through the food chain and bioaccumulate by longterm exposure in animals and humans (Sang and Li 2004). Many of the organic and inorganic leachate components were recognized as mutagens and carcinogens (Schrab 1993). They may pose a serious thread to human health causing cancer, genetic diseases and birth defects (Cabrera and Rodriguez 1999). It was recently reported that leachates induce micronuclei in bone marrow cells in mice (Li et al. 2004, Sang and Li 2005).

Therefore it seems an important tusk to monitor the toxic and especially genotoxic potential of municipal landfill leachates. Higher plants provide a very useful, uncomplicated and inexpensive tool for first-step screening of environmental pollutants. Anaphase 
and telophase aberrations (AAT) such as chromosome fragments, bridges and vagrant chromosomes are often-used biological endpoints for genotoxicity (Cabrera and Rodriguez 1999; Stopper and Muller 1997; Rank and Nielsen 1993). Some bioassays have been validated in international collaborative studies under the United Nations Environment Program, World Health Organization and US Environmental Protection Agency and are recommended for environmental monitoring (Grant 1994; Gopalan 1999).

The objective of our study was to evaluate the phytotoxicity and potential genotoxicity of Radiowo municipal landfill leachate by the means of plant bioassays and to preliminary valuate the efficiency of zeolite as a leachate purifier decreasing its toxic and genotoxic potential.

\section{METHODS}

Raw leachate was sampled from the base line of the Radiowo municipal landfill situated in the north-western part of Warsaw. Half of the leachate was filtered in small filtration column filled with a mixture of Slovakian zeolite and river sand $(80: 20)$.

The phytotoxicity and genotoxicity tests were performed for $100 \%$ leachates (raw or filtered) and leachates diluted with water to obtain $50 ; 25 ; 12.5 ; 6.25$; 3.12 ; and $1.56 \% \mathrm{v} / \mathrm{v}$ concentrations. Physiological toxicity was assessed by the Allium cepa Root Elongation Bioassay according to Fiskesjo (1985). EC50 (effective concentration reducing root length to $50 \%$ of control one) and EC10 values were assessed for raw and filtered leachate to compare their toxic potentials.

Potential genotoxicity was evaluated by the means of Allium and Vicia Root Tip Assays (RTA) according to Fiskesjo (1985) and Kanaya et al. (1994) respectively, with tap water as control. Anaphase and telophase aberrations (AAT) were observed in 100 anaphase and telophase cells of root meristems of Allium cepa (cv. Sochaczewska) and Vicia faba var. minor (cv. Nadwiślański). Results were subjected to the F-test for the two-way analysis of variance (ANOVA 2) and subsequently the Tukey's test, with statistical significance set at $\mathrm{p}=0.05$.

\section{RESULTS AND DISCUSSION}

Raw leachate from the municipal landfill of Radiowo was highly toxic to Allium cepa (Tab.1). It caused 95\% toxic effect, which means that the roots achieved only $5 \%$ the length of the control ones. Zeolite filtration very significantly decreased the toxicity of the leachate (EC 50 rose from

TABLE 1. Phytotoxicity characteristics of Radiowo landfill leachates: raw and zeolite filtered, valuated by the Allium cepa root elongation bioassay [\%]

\begin{tabular}{|l|c|c|c|}
\hline Leachate type & $\begin{array}{c}\text { Phytotoxic effect } \\
\text { in } 100 \% \text { concentration }\end{array}$ & EC 50 & EC 10 \\
\hline Raw & 95 & 26.0 & 1.4 \\
\hline Zeolite filtered & 65 & 70.0 & 5.6 \\
\hline
\end{tabular}


$26 \%$ up to $70 \%$ ) but did not eliminate it. Filtered leachate may be considered non-toxic in 5.6\% v/v (EC10) and lower concentrations, while the raw one in $1.4 \%$ or lower.

It should be admitted that the Allium cepa Root Elongation Bioassay is a very sensitive one and may be utilized for quality control of treated wastewaters (Nielsen and Rank 1994) or even drinking water (Fiskesjo 1985). In the tests with seedlings of Brassica chinensis or Cynodon dactylon other authors observed root growth inhibition in much higher $(25 \% \mathrm{v} / \mathrm{v})$ leachate concentrations (Tong and Wong 1984).

According to the results of Allium cepa (Fig. 1) and Vicia faba (Fig. 2) Root Tip Assays, $100 \%$ raw leachate turned out to be genotoxic towards the test plants. The frequency of aberrant ana-telophases AAT was significantly higher in comparison with control and the process of zeolite filtration did not decrease it. Genotoxicity however dropped in a concentration dependent manner for both leachates; more rapidly for the zeolite filtered one. It may be considered non-genotoxic for Vicia in the concentration of $6 \%$ and in $3 \%$ also for Allium, while the raw leachate was genotoxic towards both test plants even in the lowest $1.5 \%$ concentration.

Cytogenetic changes caused by municipal leachates in plants such as Hordeum, Triticum, Tradescantia, Vicia and Allium, reported by numerous authors (Sang et al. 2006, Li et al. 2008, Cabrera et al. 1999, Obidoska et al. 2006), are probably the result of cytotoxic organic

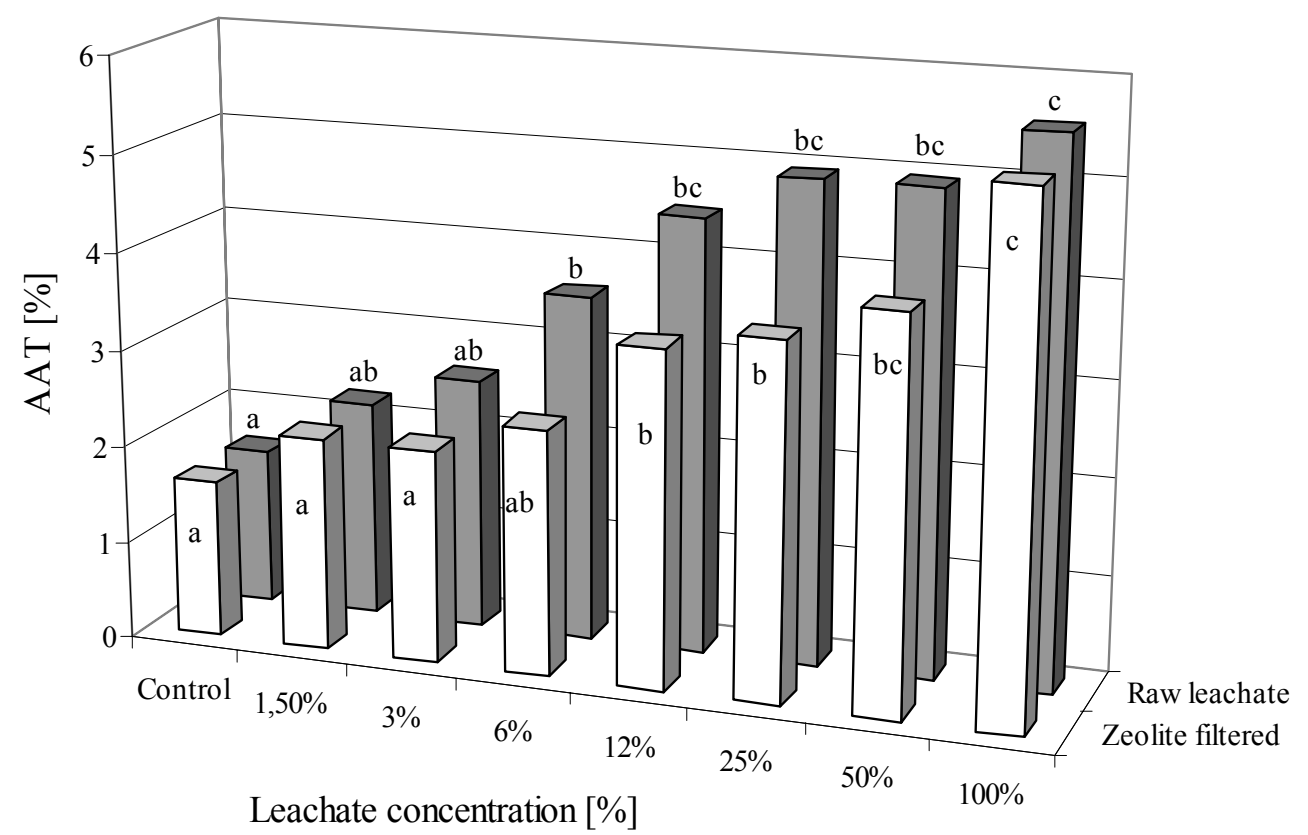

FIGURE 1. Genotoxicity of Radiowo landfill leachates: raw and zeolite filtered, measured by the frequency of ana-telophase aberrations (AAT) in meristematic root cells of Allium cepa (Means signed with the same letters do not differ significantly) 


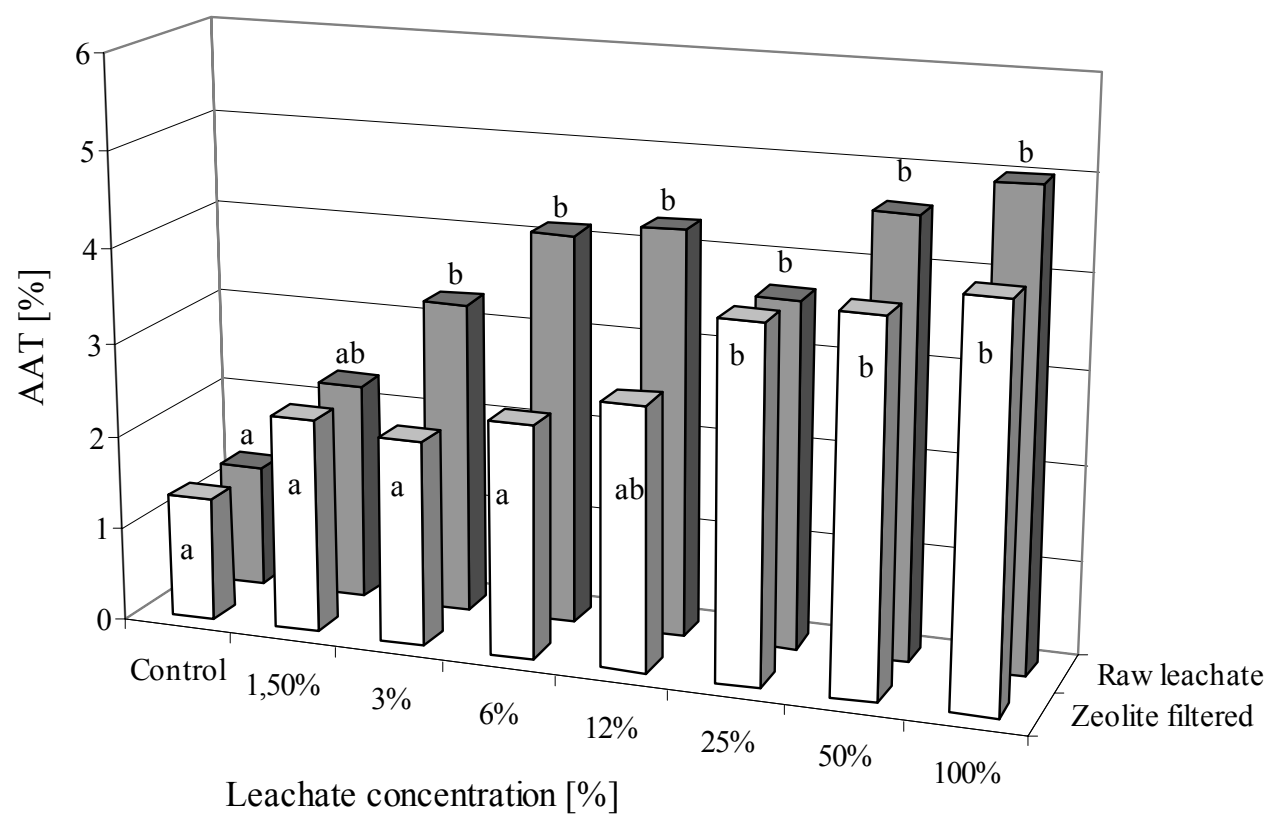

FIGURE 2. Genotoxicity of Radiowo landfill leachates: raw and zeolite filtered, measured by the frequency of ana-telophase aberrations (AAT) in meristematic root cells of Vicia faba (Means signed with the same letters do not differ significantly)

complexes and heavy metals (Li et al. 2008). Removal of heavy metals using zeolite was found to be more efficient for some ions: $\mathrm{Zn}, \mathrm{Cu}$, than others: $\mathrm{Ni}$, As (Kayabali and Kezer 1998). This perhaps may partly explain the observed low zeolite effectiveness in genotoxicity eliminating. Nevertheless the filtration process probably decreased the salinity level of the leachate and lowered down the physiological toxicity towards Allium which is not a salt-tolerant species.

\section{CONCLUSIONS}

1. Allium cepa Root Elongation Test indicated a significant phytotoxicity of Radiowo landfill leachate.

2. The leachate was genotoxic towards the applied test plants Allium and
Vicia, which may suggest its potential genotoxic effect in other organisms.

3. The process of zeolite filtration did not eliminate the phytotoxicity of leachate but evidently decreased it (EC 50 from $26 \%$ rose to $70 \%$ ).

4. Zeolite filtration did not cause significant change in genotoxic potential of $100 \%$ leachate in Allium and Vicia, but resulted in its more rapid decrease in a concentration dependent manner.

\section{REFERENCES}

CABRERA G.L., RODRIGUEZ D.M.G. 1999: Genotoxicity of leachates from a landfill using three bioassays. Mut. Res., 426: 207-210. 
CABRERA G.L., RODRIGUEZ D.M.G., MARURI A.B. 1999: Genotoxicity of the extract from the compost of the organic and the total municipal garbage using three plant bioassays. Mut. Res., 426: 201-206.

FISKESJO G. 1985: The Allium test a standard in environmental monitoring. Hereditas 102: 99-112.

GOPALAN H.N.B. 1999: Ecosystem health and human well being: the mission of the international programme on plant bioassays. Mut. Res., 426: 99-102.

GRANT W.F. 1994: The present status of higher plant bioassays for the detection of environmental mutagens. Mut. Res. 310 (1994) 175-185

KANAYA N., GILL B.S., GROVER I.S., MURIN A., OSIECKA R., SANDHU S.S., ANDERSSON H.C. 1994: Vicia faba chromosomal aberration assay. Mut. Res., 310: 231-247.

KAYABALÝ K., KEZER H. 1998: Testing the ability of bentonite-amended natural zeolite (clinoptinolite) to remove heavy metals from liquid waste. Environ. Geol., $34(2 / 3)$

LIG., SANGN.,ZHAOY. 2004: Micronuclei induced by municipal landfill leachate in mouse bone marrow cells in vivo. Environ. Res., 95: 77-81.

LI G., YUN Y., LI H., SANG N. 2008: Effect of landfill leachate on cell cycle, micronucleus and sister chromatid exchange in Triticum aestivum. $J$. Hazard. Materials, 155: 10-16.

NIELSEN M.H., RANK J. 1994: Screening of toxicity and genotoxicity in wastewater by the use of the Allium test. Hereditas, 121: 249-254.

OBIDOSKA G., SADOWSKA A., RUBCZEWSKA M. 2006. Validation of plant bioassays for environmental genotoxicity evaluation at Łubna landfill. Ann. Warsaw Agricult. Univ. - SGGW, Horticult. Landsc. Architect. 27: 51-57.

RANK J., NIELSEN M.H. 1993: A modified Allium test as a tool in the screening of the genotoxicity of complex mixtures. Hereditas, 118: 49-53.

SANG N., LI G. 2004: Genotoxicity of municipal landfill leachate on root tips of Vicia faba. Mut. Res., 560: 159-165.

SANG N., LI G. 2005: Chromosomal aberrations induced in mouse bone marrow cells by municipal landfill leachate. Environ. Tox. Pharm., 20: 219-224.

SANG N., LI G. 2006: Municipal landfill leachate induces cytogenetic damage in root tips of Hordeum vulgare. Ecotoxicol. Environ. Safety, 63: 469-473.

SCHRAB G.E., BROWN K.W., DONNELLY K.C. 1993: Acute and genetic toxicity of municipal landfill leachate. Water Air Soil Pollut., 69: 99-112.

STOPPER H., MULLER S.O. 1997: Micronuclei as a biological endpoint for genotoxicity: a minireview. Toxicol. in Vitro 11: 661-667.

TONG S.T.Y., WONG M.H. 1984: Bioassay tests of landfill leachate using Brassica chinensis and Cynodon dactylon. Conservation and Recycling, 7: 283-294.

Streszczenie: Fitotoksyczność i potencjalna genotoksyczność odcieku z komunalnego wysypiska odpadów Radiowo. Najpowszechniejszą metodą postępowania ze stałymi odpadami komunalnymi jest ich składowanie na wysypiskach. W odpadach znajduje się wiele szkodliwych substancji, a kolejne powstają w wyniku ich degradacji. Moga one zostać pobrane przez liczne organizmy żywe i przeszedłszy drogę łańcucha pokarmowego, podlegać bioakumulacji w tkankach zwierząt i ludzi eksponowanych na ich działanie. $Z$ tego względu monitorowanie toksycznego i genotoksycznego potencjału odcieków z wysypisk odpadów komunalnych, mogących zanieczyszczać wody i gleby, wydaje się być istotne. Rośliny wyższe są podstawą bardzo użytecznych, prostych i niedrogich metod skriningu zanieczyszczeń środowiska. Celem naszej pracy była ocena fitotoksyczności i potencjalnej genotoksyczności odcieku z komunalnego wysypiska odpadów Radiowo za pomocą testów roślinnych oraz wstępna ocena zastosowania zeolitu jako sposobu jego oczyszczania. Fitotoksyczność została oszacowana za pomocą testu 
elongacji korzeni u Allium cepa, natomiast genotoksyczność testami stożków wzrostu korzeni u Allium cepa i Vicia faba. Wyniki zostały poddane dwuczynnikowej analizie wariancji (F-test), a następnie testowi Tukeya przy poziomie istotności $\mathrm{p}=0,05$. Zastosowane testy wskazywały na wysoką fitotoksyczność i potencjalną genotoksyczność odcieku z wysypiska Radiowo. Proces filtracji przed zeolit nie wyeliminował, lecz ewidentnie obniżył fitotoksyczność. Nie wpłynął znacząco na potencjał genotoksyczny $100 \%$ odcieku, ale spowodował bardziej gwałtowny jego spadek przy wzrastającym rozcieńczeniu.
MS. received August 2008

\author{
Authors' address: \\ Grażyna Obidoska, Dorota Jasińska \\ Katedra Ochrony Środowiska SGGW \\ 02-787 Warszawa, ul. Nowoursynowska 166 \\ Poland \\ e-mail: grazyna_obidoska@sggw.pl
}

